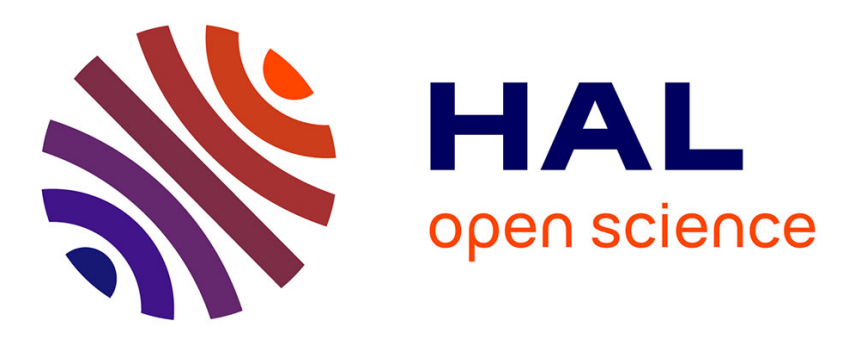

\title{
Synthesis of 1,8-Diazaanthracenes as Building Blocks for Internally Functionalized Aromatic Oligoamide Foldamers
}

Michael L. Singleton, Nicola Castellucci, Stéphane Massip, Brice Kauffmann, Yann Ferrand, Ivan Huc

\section{To cite this version:}

Michael L. Singleton, Nicola Castellucci, Stéphane Massip, Brice Kauffmann, Yann Ferrand, et al.. Synthesis of 1,8-Diazaanthracenes as Building Blocks for Internally Functionalized Aromatic Oligoamide Foldamers. Journal of Organic Chemistry, 2014, 79 (5), pp.2115-2122. $10.1021 /$ jo402852m . hal-01509467

\section{HAL Id: hal-01509467 \\ https://hal.science/hal-01509467}

Submitted on 18 Apr 2017

HAL is a multi-disciplinary open access archive for the deposit and dissemination of scientific research documents, whether they are published or not. The documents may come from teaching and research institutions in France or abroad, or from public or private research centers.
L'archive ouverte pluridisciplinaire HAL, est destinée au dépôt et à la diffusion de documents scientifiques de niveau recherche, publiés ou non, émanant des établissements d'enseignement et de recherche français ou étrangers, des laboratoires publics ou privés. 


\title{
Synthesis of 1,8-diazaanthracenes as building blocks for in- ternally functionalized aromatic oligoamide foldamers
}

\author{
Michael L. Singleton, ${ }^{\dagger,}$ Nicola Castellucci, ${ }^{\dagger, \uparrow, \mid}$ Stéphane Massip, ${ }^{\ddagger, \#, \S}$ Brice Kauffmann, ${ }^{\ddagger}, \#, \S$ \\ Yann Ferrand, ${ }^{\dagger, \oplus}$ Ivan Huc ${ }^{*}, \dagger, \uparrow$ \\ $\dagger$ Univ. Bordeaux, CBMN (UMR 5248), Institut Européen de Chimie Biologie, 2 rue Escarpit 33600 Pessac, France \\ II CNRS, CBMN (UMR 5248), France \\ | Dipartimento di Chimica “G. Ciamician” Alma Mater Studiorum Università di Bologna via Selmi 2, 40126 Bologna, Italy \\ \$ Univ. Bordeaux, Institut Européen de Chimie Biologie (UMS 3033/US 001), 2 rue Escarpit, 33600 Pessac, France \\ \# CNRS, Institut Européen de Chimie Biologie (UMS 3033), France \\ $\S$ INSERM, Institut Européen de Chimie Biologie (US 001), France \\ *i.huc@iecb.u-bordeaux.fr
}

KEYWORDS: pyrido[3,2g]quinolines, diazaanthracenes, aromatic amino acids, foldamers

\begin{abstract}
The synthesis of a variety of 9-functionalized 1,8-diazaanthracene diesters and amino acids is described. Derivatization in the 9-position relies on facile reactions performed on the 9-chloro and 9-bromomethyl precursors. This has allowed the incorporation of nucleophilic or sensitive functional groups that otherwise cannot be incorporated under standard methods for synthesizing these compounds. Additionally, the synthesis of the protected amino acids via a high yielding monosaponification and subsequent Curtius rearrangement has been accomplished on multi-gram scale. These units, together with the functionalized derivatives should prove to be useful monomers in the synthesis of aromatic oligoamide foldamers.
\end{abstract}

\section{Introduction}

The last decade has seen a significant advancement in the synthesis of molecules designed to mimic both structural and functional aspects of biopolymers. ${ }^{1,2}$ Chemists can now readily synthesize oligomeric or even polymeric systems that, through the same principles that direct folding in biological molecules, adopt complex secondary structural features including helices, linear strands and, more rarely, sheets. ${ }^{3-8}$ These artificial folded molecular architectures, termed foldamers, ${ }^{9}$ are typically comprised of small distinct units that, when connected together, self-organize into specifically shaped macromolecules, the properties of which are dependent on the composition of monomers used. In this respect, the development of new foldamers can be said to be monomer driven. Thus, the synthesis of novel monomer units is an important endeavor for expanding the diversity of this class of molecules.

While the majority of synthetic foldamers make use of aliphatic units derived from $\alpha$-amino acids or the homologous $\beta$ and $\gamma$-amino acids, ${ }^{10-12}$ the myriad of chemical building blocks afforded to chemists has given rise to folded systems more distinctly removed from their natural counterparts. These include, but are not limited to, oligomers comprised of $\mathrm{m}$ phenylene ethynylenes, ${ }^{13,14}$ pyridine-pyridizines, ${ }^{15,16}$ ureas, ${ }^{17,18}$ and aromatic amides. ${ }^{19,20}$ This last group, aromatic oligoamide foldamers, has shown particular promise in the development of complex architectures as a result of their high predictability, stability, and tunability.

The connection of aromatic rings via an amide linkage gives a planar or close to planar system as a result of conjugation.
Thus, with a functionalized aromatic ring, one of two conformations can be expected, with the preference for syn versus anti dictated by the local attractive and repulsive electrostatic interactions between the amide and any endo- or exocyclic heteroatoms on the ring, (Figure 1a). ${ }^{19,20}$ Extension of these principles to subsequent monomers consequently results in an overall structure that is defined by the collection of local conformational preferences. In the case of helical structures, where these preferences bring the additional monomers around in a full turn, steric interactions result in the strand being twisted out of planarity and the secondary structure that begins to form being further stabilized by aromatic $\pi-\pi$ stacking interactions.

Monomers for these designs, (Figure 1b, c), as long as they fulfill the structural requirements described above, can be readily modified to tune many of the properties of the foldamers including solubility, curvature, or aggregative tendencies. Specifically, by tuning the width of the monomers in a sequence and the angle between their amino and carboxy groups, large cavities capable of encapsulating guest molecules can be developed. Several such systems based on aromatic oligoamides have now been reported. ${ }^{21-26}$ However, current limitations on these systems involve both limited cavity sizes and limited functional group diversity on the interior surfaces.

Pyrido-[3,2-g]quinolines, hereafter referred to as 1,8diazaanthracenes in this manuscript (Figure 1c), represent an attractive candidate for expanding both the size and interior complexity of such helical receptors. These units offer a long 
distance $(\sim 9 \AA)$ and wide angle $\left(\sim 120^{\circ}\right)$ between connection sites at positions 2 and 7 , which can allow interior cavities of exceptionally large size to be synthesized. Additionally, because only the outer two aromatic rings are used for structural stability by means of their endocyclic nitrogen atom, the central ring, i.e. position 9, can be modified in order to potentially provide enhanced interactions between the host and guest molecules or even provide catalytic sites through the use of functional groups that converge towards the interior of a helical cavity, (Figure 1d). As a class of molecules, 1,8diazaanthracenes have been studied for both their photophysical and pharmaceutical applications. ${ }^{27-30}$ Despite this, the variety of such compounds is not extensive, and while units of this type have been used in the development of helical aromatic oligoamides, ${ }^{24-26,31-34}$ their diversity has been limited to the two units shown in Figure 1c.

(a)

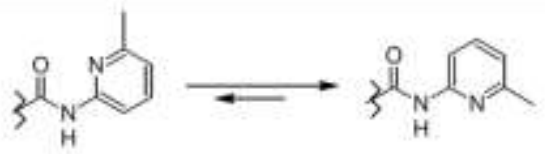

(b)

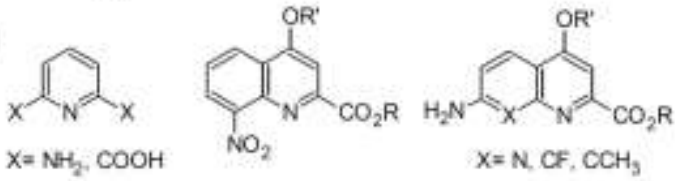

(c)

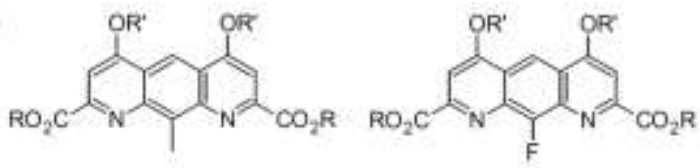

(d)

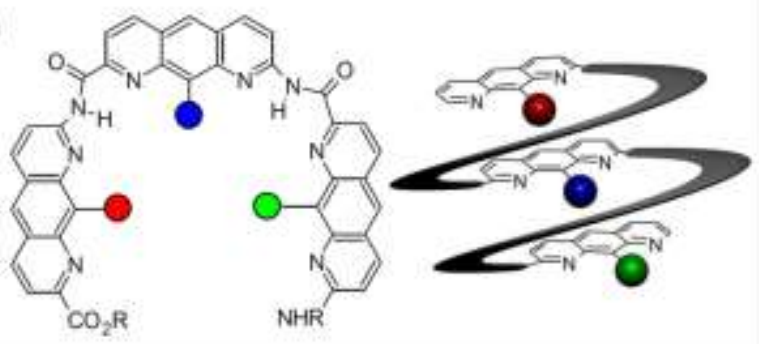

Figure 1. (a) Conformational exchange between syn and anti forms of an aromatic amide. (b, c) Examples of aromatic building blocks for aromatic oligoamides, including 1,8-diazaanthracenes (c) that have been used for foldamer synthesis. (d) Potential ways for using 1,8-diazaanthracenes for arranging convergent functional groups in a helical foldamer scaffolds

\section{Scheme 1. Typical synthesis of 1,8-diazaanthracenes ${ }^{\mathrm{a}}$}
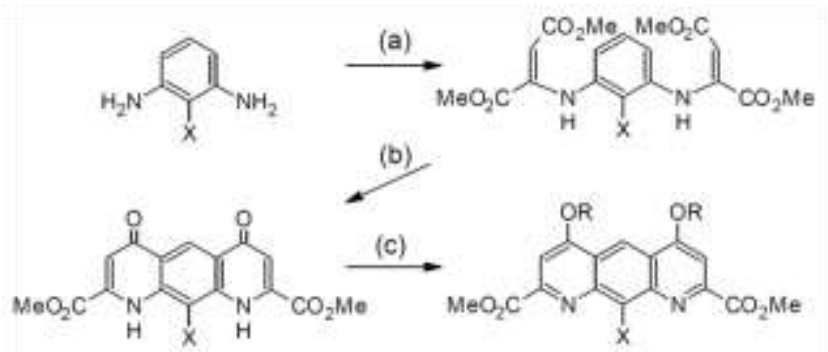

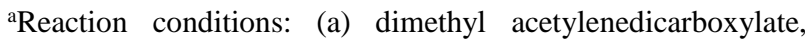
$\mathrm{MeOH}$; (b) $\mathrm{Ph}_{2} \mathrm{O}, \Delta$; (c) diisopropyl azodicarboxylate, $\mathrm{PPh}_{3}$, $\mathrm{ROH}, \mathrm{THF}$
The typical synthetic route to make these molecules likely contributes to this limited diversity (Scheme 1). The synthesis is accomplished via an initial Michael addition of two equivalents of dimethyl acetylenedicarboxylate to the appropriate 1functionalized-2,6-diaminobenzene. ${ }^{27}$ Thermal cyclization in refluxing diphenyl ether at $260^{\circ} \mathrm{C}$ and then alkylation of the resulting 4,5-dihydroxy-1,8-diazaanthracenes under Mitsunobu conditions gives the final monomers. ${ }^{23,26,33}$ Through this protocol, variation of the 9-position substituent is limited to the range of functional groups that can be incorporated into the starting diaminobenzene moiety and that are capable of withstanding the harsh conditions of the cyclization step, i.e. either high temperature, ${ }^{27}$ or strongly acidic conditions. ${ }^{35}$ In addition, this route requires a substituent on the diamino-benzene precursor, and does not allow to directly reach the 9- $\mathrm{H} 1,8$ diazaanthracene. Without this substituent, a 1,7-phenanthroline is obtained instead of a 1,8-diazaanthracene. ${ }^{27,36}$

For modification of the 9- position, it would be ideal to have monomers that could be readily modified after their initial synthesis. The current work provides methods for easily introducing a number of aromatic and alkyl functional groups at the 9-position of the diazaanthracene monomers. Furthermore, because functionalization takes place after the cyclization step, previously unobtainable monomers, such as the 9-hydro derivative, are now accessible. ${ }^{27,36}$

Additionally, the synthetic route affords symmetrical units having ester functional groups both in the 2- and 7- positions. This has until now hampered the production of multimeric segments of 1,8-diazaanthracene units, their development being limited to the use of less stable connections such as anhydrides. ${ }^{33}$ In order to increase the applicability of these units in the synthesis of aromatic oligoamides, two methods for the desymmetrization of the monomers and formation of the amino acids are reported here. Through these synthetic routes, a novel class of large aromatic amino acids with a variety of side-chains has been obtained.

\section{Results and Discussion}

Derivatization of the 9-position of the diazaanthracenes. As shown in Scheme 2, the starting materials for diversification of the diazaanthracene series are the 9-methyl ${ }^{34}$ (compound 1) and 9-chloro (compound 2-Cl) derivatives, both readily obtained from reaction of the corresponding pyridoquinolinone with isobutyl alcohol under Mitsunobu conditions. Compound $\mathbf{1}$ can be brominated in the benzylic position using N-bromosuccinimide and benzoyl peroxide to give compound 1-Br in good yield (89\%). Subsequent substitution of the bromide by reaction of $\mathrm{Ag}_{2} \mathrm{CO}_{3}, \mathrm{AgOAc}$, or $\mathrm{AgONO}_{2}$ gave the derivatives 1-OH, 1-OAc, and 1-ONO 2 respectively. Interestingly, while both the acetate and nitrate ester groups were initially planned as methods for getting to the alcohol, the nitrate ester proved resistant to hydrolysis by water and attempted transesterification of the acetate derivative by methanol in the presence of catalytic sulfuric acid instead resulted in the formation of the methyl ether derivative 1-OMe. The nitrate ester, however, appears to be a reasonable precursor for synthesis of the aldehyde derivative, $\mathbf{1 = 0}$, by reaction with multiple equivalents of $\mathrm{Et}_{3} \mathrm{~N}$ in refluxing dimethoxyethane.

Nitrogen containing side chains are similarly incorporated. The reaction of five equivalents of sodium azide with $\mathbf{1 - B r}$ in the presence of 15 -crown-5 proceeds at room temperature to give 1-N $\mathbf{N}_{3}$ in good yield. However, attempted reduction of the azide to the amine did not give good conversion by either 
standard reduction with $\mathrm{Pd} / \mathrm{C}$ and $\mathrm{H}_{2}$ or by Staudinger reduction using $\mathrm{PPh}_{3}$. Instead a Gabriel type synthesis of the amine was used by initially substituting $\mathbf{1 - B r}$ with di-tertbutylimidocarbonate to give the bis(tert-butoxycarbonyl) protected benzylic amine. ${ }^{37}$ Selective mono-Boc deprotection using $\mathrm{Mg}\left(\mathrm{ClO}_{4}\right)_{2}$ in refluxing $\mathrm{MeCN}$ gave derivative 1NHBoc in $80 \%$ yield across the two steps.

\section{Scheme 2. Derivatization of diazaanthracene units. ${ }^{a}$}
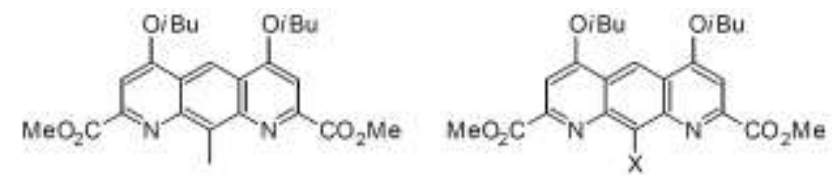

1
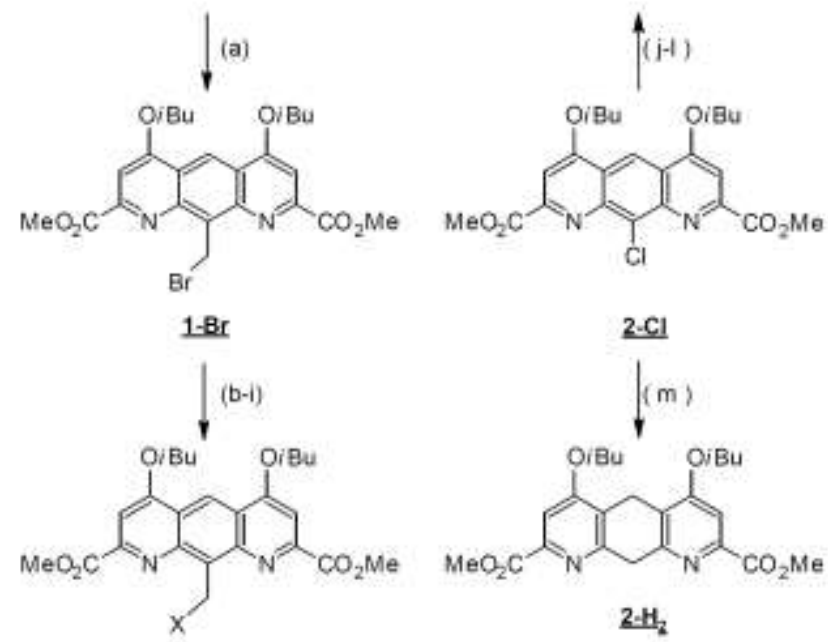

1-X: $\mathrm{X}=\mathrm{OH}$ (b); $\mathrm{OAc}$ (c); $\mathrm{ONO}_{2}$ (d): OMe $(e)$; $=\mathrm{O}(\mathrm{f}) ; \mathrm{N}_{3}(\mathrm{~g}) ; \mathrm{NHBoc}(\mathrm{h})$; imic

(i)

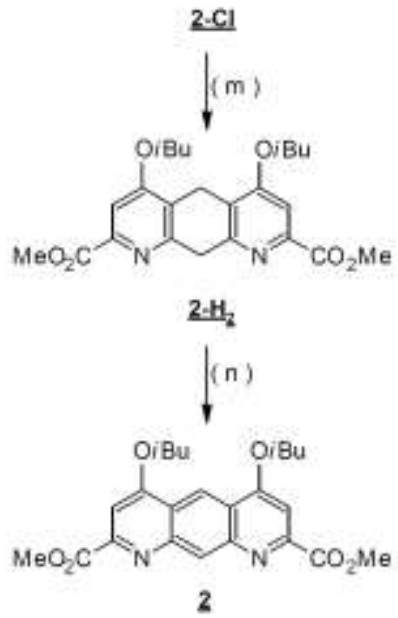

${ }^{a}$ Reaction conditions: (a) NBS, BPO, $\mathrm{C}_{6} \mathrm{H}_{6}, 60^{\circ} \mathrm{C}, 89 \%$; (b) $\mathrm{Ag}_{2} \mathrm{CO}_{3}$, dioxane $/ \mathrm{H}_{2} \mathrm{O}, \Delta, 80 \%$; (c) AgOAc, dioxane, 91\%; (d) $\mathrm{AgONO}_{2}$, dioxane, 81\%; (e) 1.1. AgOAc, dioxane; 1.2. $\mathrm{MeOH}$, $\mathrm{H}_{2} \mathrm{SO}_{4}$ cat. $80 \%$; (f) $\mathrm{AgONO}_{2}$, dioxane, then Et $3 \mathrm{~N}$, dioxane, $\Delta$, 41\%; (g) $\mathrm{NaN}_{3}$, 15-crown-5, dioxane, 71\% (h) 1.1. KNBoc2, DMF, $50{ }^{\circ} \mathrm{C}$; 1.2. $\mathrm{Mg}\left(\mathrm{ClO}_{4}\right)_{2}, \mathrm{MeCN}, \Delta, 80 \%$; (i) Methylimidazole, $\Delta, 83 \%$; (j) $\mathrm{NaN}_{3}, \mathrm{PPh}_{3}$, DMF, $\Delta, 61 \%$; (k) $\mathrm{NaN}_{3}, \mathrm{PPh}_{3}$, DMF, $\Delta$, then $\mathrm{Boc}_{2} \mathrm{O}$, DMAP, dioxane, $\Delta, 80 \%$; (l) HSBn, $\mathrm{Cs}_{2} \mathrm{CO}_{3}$, toluene $86 \%$; (m) $\mathrm{Pd} / \mathrm{C}, \mathrm{H}_{2}, \mathrm{~K}_{2} \mathrm{CO}_{3}, \mathrm{DMF}, 79 \%$; (n) $\mathrm{C} / \mathrm{O}_{2}$, toluene, $100{ }^{\circ} \mathrm{C} 83 \%$.

Cationic nitrogen centers could also be generated quite readily. Reaction of N-methylimidazole with $\mathbf{1 - B r}$ gave the imidazolium salt, 1-imid, in $83 \%$ yield after precipitation in diethyl ether. In addition to the positive charge that it can provide, this derivative could also provide carbene based reactivity inside of a foldamer capsule.

Compound 2-Cl could similarly be derivatized through nucleophilic displacement of the chloride. Sulfur based nucleophiles readily add to the diazaanthracene. Even at room temperature, the reaction of benzyl mercaptan with $\mathbf{2 - C l}$ in the presence of $\mathrm{Cs}_{2} \mathrm{CO}_{3}$ proceeds to give 2-SBn as a bright red solid in $86 \%$ yield.

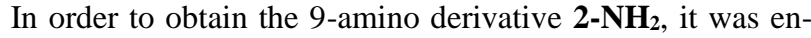
visaged that reaction with $\mathrm{NaN}_{3}$ in DMF would give an intermediate azide bearing diazaanthracene that could be reduced to give the amine. However, at the temperatures required for substitution to occur, the resulting azide decomposed, presumably to the nitrene and gave a mixture of species including the amine, in low yield $(<30 \%)$, as well as an unstable species assigned to the 9-azido complex based on a strong IR signal at $2116 \mathrm{~cm}^{-1}$ ( $\mathrm{KBr}$ pellet), and several unidentified species attributed to decomposition products resulting from side reactions with the nitrene intermediate. By combining the displacement and reductive steps through the addition of $\mathrm{PPh}_{3}$ to the reaction mixture, as described by Kandakar et al., ${ }^{38}$ the yield could be greatly increased $(61 \%)$ and the amine obtained as a bright red crystalline solid after work-up.

Protection of $\mathbf{2}-\mathbf{N H}_{2}$ by reaction with $\mathrm{Boc}_{2} \mathrm{O}$ proceeds only at high temperatures and with the addition of DMAP. Under these conditions, the reaction cannot be stopped at the monoBoc complex. Rather, even when the reaction is stopped before completion, only starting material and the di-Boc complex 2-NBoc 2 are observed.

Most importantly for complex 2-Cl, it provides a method for the synthesis of the 9-hydro compound, 2, an ideal unit for designing large cavities because of its lack of space filling functional groups. Hydrodehalogenation of 2-Cl occurs readily in DMF with $\mathrm{K}_{2} \mathrm{CO}_{3}$ as a base. The use of a weaker base like $\mathrm{Et}_{3} \mathrm{~N}$ or less polar solvent does not give the desired hydrodehalogenation, rather the major product is a 1,2,3,4tetrahydropyrido[3,2g]quinoline species, 2-Cl ${ }^{\text {red }}$ (Figure 2c), resulting from reduction of one of the pyridine rings. Even under the ideal conditions the initial product from the hydrodehalogenation, the 9-hydro compound $\mathbf{2}$ is further reduced to the 9,10-dihydro compound $\mathbf{2}-\mathbf{H}_{2}$. Despite best efforts to stop the reaction before the second reduction occurs, a mixture of both products was always obtained. Compound $\mathbf{2}-\mathbf{H}_{\mathbf{2}}$ can however, be reoxidized back to the fully aromatic 2 .

While several conditions for the reoxidation were tested including $\mathrm{MnO}_{2}, \mathrm{DDQ}$, and $\mathrm{Pd} / \mathrm{C}$ under $\mathrm{N}_{2}$, the best results were obtained from activated $\mathrm{C}$ and $\mathrm{O}_{2}{ }^{39}$ in refluxing toluene. Reaction progress was monitored by ${ }^{1} \mathrm{H}-\mathrm{NMR}$ through loss of the triplet signals at 4.53 and $4.07 \mathrm{ppm}$ and the appearance of two singlets at 9.29 and $9.20 \mathrm{ppm}$ consistent with the oxidation of the central ring. The combined yield for both the reduction and reoxidation steps is close to $66 \%$ and compound $\mathbf{2}$ can be obtained in multi-gram quantities. The lack of a functional group in the 9 position now allows other derivatives to be synthesized through electrophilic aromatic reactions. As one example, $\mathbf{2}$ was converted into the 9-bromo compound $\mathbf{2 - B r}$ through reaction with NBS at elevated temperature.

Compounds $\mathbf{2}, \mathbf{2}-\mathbf{H}_{2}$, and the byproduct with the reduced pyridine ring were all characterized by X-ray crystallography, (Figure 2). While the byproduct, (Figure 2c), shows significant differences from either $\mathbf{2}$ or $\mathbf{2}-\mathbf{H}_{\mathbf{2}}$, the latter compounds are very similar in structure with the central ring of $\mathbf{2}-\mathbf{H}_{2}$ showing only minor distortion into a chair conformation. The change in $\mathrm{C}-\mathrm{C}$ bond lengths between the 9 or 10 position carbons and the adjacent pyridine rings, $1.49 \AA$ in $\mathbf{2}-\mathbf{H}_{2}$ to $1.40 \AA$ in $\mathbf{2}$, is nevertheless consistent with the different degrees of saturation in the central ring.

\section{Desymmetrization and Amino Acid Synthesis.}

As stated earlier, for the facile synthesis of diazaanthracene oligoamide segments, it would be ideal to develop amino acid 
derivatives. This involves two important steps; the first is the desymmetrization by monosaponification of the equivalent diesters and the second is the conversion of the resulting acid into the protected amine functionality. As shown in Scheme 3, the synthetic approach is different depending on the starting compound.
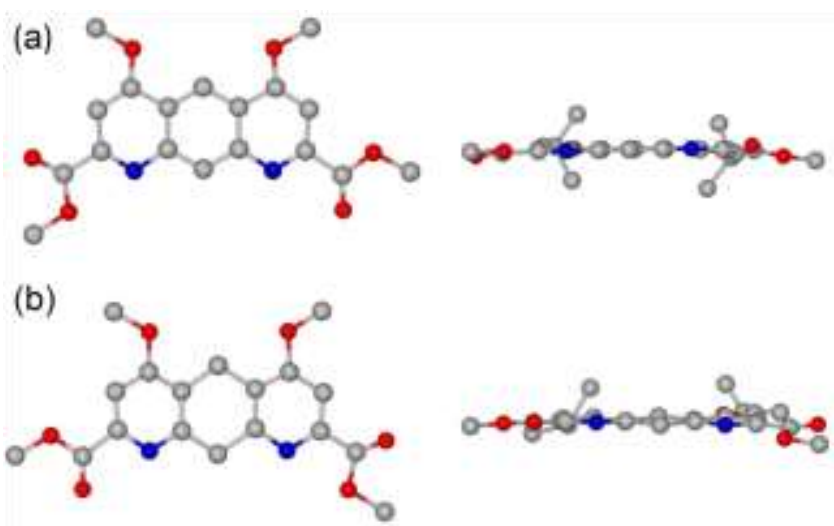

(c)
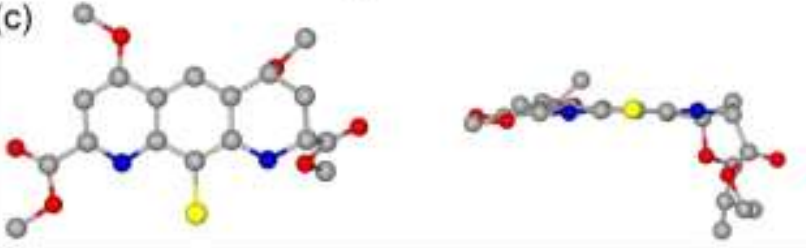

Figure 2. Top (left) and side (right) views of ball and stick representations of the X-ray crystal structures of (a) 2, (b) $2-\mathrm{H}_{2}$, and (c) the tetrahydropyrido[3,2g]quinoline byproduct (2-Cled $)$ from failed hydrodehalogentaion attempts. Protons and included solvent molecules have been removed and, in the top view, isobutoxy side chains have been shortened for clarity

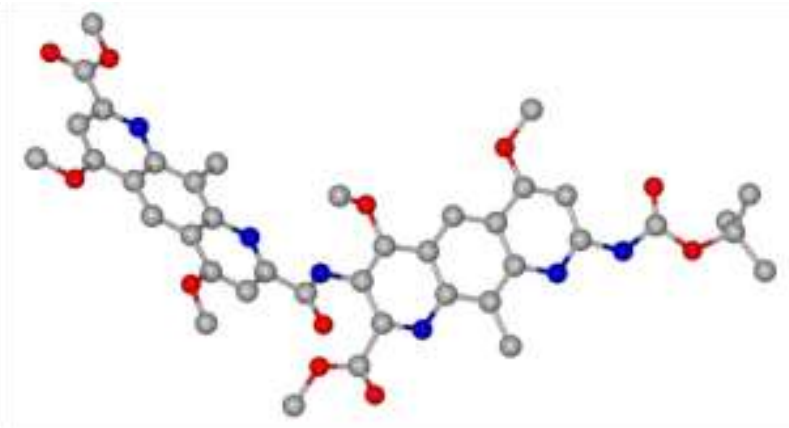

Figure 3. Ball and Stick representation of the X-ray crystal structures of dimeric byproduct 4-dimer. Protons and included solvent molecules have been removed and isobutoxy side chains shortened for clarity.

For both $\mathbf{1}$ and $\mathbf{2}$, high yields in the monosaponification step rely on the limited solubility of the monocarboxylate salt. With 1, it was found that a solvent mixture of $75 / 25$ $\mathrm{THF} / \mathrm{MeOH}$ and $\mathrm{NaOH}$ as the base, gave 3-Me in the best yields, while for $\mathbf{2}$, initial solvation in hot methanol followed by the addition of $\mathrm{KOH}$ afforded $\mathbf{3}$ in $90 \%$ yield after a short reaction time at $60{ }^{\circ} \mathrm{C}$ followed by reaction overnight at $35^{\circ} \mathrm{C}$. For both compounds the carboxylate salt precipitates out and can be isolated in pure form by filtration. For 3-Me, the compound was left as the sodium salt and used this way for subsequent steps, while for $\mathbf{3}$, the product was washed with a citric acid solution to obtain the acid. Compound 3-Me was convert- ed into the Boc protected amino acid through initial reaction with oxalyl chloride followed by acyl azide formation with trimethylsilyl azide. The Curtius rearrangement was performed in refluxing tert-butanol to give the Boc protected amine 4-Me. As a side product of this reaction, a dimeric species, 4-dimer, was observed where the nitrene that formed during the rearrangement underwent an intermolecular $\mathrm{C}-\mathrm{H}$ insertion at the position ortho to the methyl ester in a second molecule of diazaanthracene, (Figure 3). While the formation of this side product could be limited by further dilution of the reaction, it was never fully eliminated under the conditions used.

Scheme 3. Synthesis of protected amino acids 4 and 4-Me. ${ }^{a}$<smiles>CCCCOc1cc(OCC)nc2c(I)c3nc(C(C)=O)cc(OCC)c3cc12</smiles><smiles>CCCCOc1cc(C(C)=O)nc2cc3nc(C(C)=O)cc(OCC)c3cc12</smiles><smiles>CCOc1cc(C(C)=O)nc2c(C)c3nc(C(=O)O)cc(OCC)c3cc12</smiles><smiles>CCOc1cc(C(=O)O)nc2cc3nc(C(C)=O)cc(OCC(C)(C)C)c3cc12</smiles><smiles>CCOc1cc(NCC(C)(C)C)nc2c(C)c3nc(C(C)=O)cc(OCC)c3cc12</smiles><smiles>CCOc1cc(NC(C)=O)nc2cc3nc(C(C)=O)cc(OCC)c3cc12</smiles>

${ }^{a}$ Reaction Conditions: (a) $\mathrm{NaOH}$, THF/MeOH, 89\%; (b) 1.1 . Oxalyl chloride, $\mathrm{CHCl}_{3} ; 1$ 1.2. $\mathrm{TMSN}_{3}, \mathrm{CHCl}_{3} ; 1.3 . t \mathrm{BuOH}, \Delta$, $77 \%$; (c) $\mathrm{KOH}, \mathrm{MeOH}, 60{ }^{\circ} \mathrm{C}-30{ }^{\circ} \mathrm{C}, 90 \%$ (d) dppa, toluene, r.t., then toluene, $t \mathrm{BuOH}, \Delta, 62 \%$.

Use of a similar scheme for $\mathbf{3}$ resulted in low yields as a result of instability during the acid chloride formation. Unlike 3Me, which stays yellow after reaction with the oxalyl chloride, a solution of $\mathbf{3}$ turns black and little or no product is obtained. Results were similar with both thionyl chloride and 1-chloro$N, N, 2$-trimethylpropenylamine. As an alternative, diphenylphosphoryl azide was used, but required first an initial reaction in toluene overnight at room temperature, followed by further dilution with toluene and $t \mathrm{BuOH}$ before heating to reflux for several hours. This dilution step is again required to limit the formation of byproducts that occur during the Curtius rearrangement.

\section{Conclusion}

All compounds described above represent derivatives that are difficult to obtain in good yield through the standard synthetic routes described for the precursors $\mathbf{1}$ and $\mathbf{2 - C l}$. Additionally, the methods for desymmetrization and conversion to the protected amino acids have provided large, rigid aromatic units that should serve as important building blocks in the development of supramolecular architectures. The synthetic routes described for these compounds offer a complementary 
method for incorporating functional groups into aromatic oligoamide foldamers for the purposes of molecular recognition or reactivity. Studies looking at incorporating these units into longer sequences are under way and will be reported in due course.

\section{Experimental}

General Procedures. Unless otherwise stated all solvents and reagents were used without further purification. When required, dry solvents and bases were obtained directly prior to use by either distillation from $\mathrm{CaH}_{2}\left(\mathrm{CHCl}_{3}\right.$, triethylamine, and diisopropylethyl amine) or dried over alumina (THF, Toluene, and DCM). All solvent mixtures for chromatography are reported as (v/v). Compound 1 and dimethyl 10-chloro4,6-dioxo-1,4,6,9-tetrahydropyrido[3,2-g]quinoline-2,8-

dicarboxylate were synthesized as previously reported. ${ }^{27,34}{ }^{1} \mathrm{H}$ and ${ }^{13} \mathrm{C}$ NMR chemical shifts are reported in ppm and are calibrated against residual ${ }^{1} \mathrm{H}$ and ${ }^{13} \mathrm{C}$ solvent signals of $\mathrm{CDCl}_{3}$ $(\delta 7.26,77.2)$ and DMSO-d6 $(\delta 2.50,39.4)$. The following notation is used for the ${ }^{1} \mathrm{H}$ NMR spectral splitting patterns: singlet (s), broad singlet (bs), doublet (d), triplet (t), multiplet (m). High resolution electrospray ionization oribitrap (ESIorbitrap) mass spectra were measured in the positive ion mode.

\section{Synthesis}

Dimethyl 1,8-diaza-4,5-diisobutoxy-9-(bromomethyl)2,7-anthracene dicarboxylate, 1-Br. In a $100 \mathrm{~mL}$ roundbottomed flask, compound $1(5.00 \mathrm{~g}, 11.0 \mathrm{mmol})$, freshly recrystallized NBS (2.15 g, $12.1 \mathrm{mmol}, 1.1$ equiv.), and benzoyl peroxide ( $1.33 \mathrm{~g}, 5.5 \mathrm{mmol}, 0.5$ equiv.) were slurried in benzene $(30 \mathrm{~mL})$. The mixture was then heated to $65^{\circ} \mathrm{C}$ and stirred overnight. Solvent was removed by rotary evaporation and the yellow residue was recrystallized from DCM/MeOH to yield the compound 1-Br as yellow crystals. (5.2 $\mathrm{g}, 89 \%$ ). ${ }^{1} \mathrm{H}$ NMR $\left(\mathrm{CDCl}_{3}, 300 \mathrm{MHz}\right): \delta 9.27(\mathrm{~s}, 1 \mathrm{H}), 7.51(\mathrm{~s}, 2 \mathrm{H}), 6.16$ $(\mathrm{s}, 2 \mathrm{H}), 4.14\left(\mathrm{~d},{ }^{3} J_{\mathrm{HH}}=6.4 \mathrm{~Hz}, 4 \mathrm{H}\right), 4.10(\mathrm{~s}, 6 \mathrm{H}), 2.36(\mathrm{~m}$, 2H), $1.19\left(\mathrm{~d},{ }^{3} \mathrm{~J}_{\mathrm{HH}}=6.8 \mathrm{~Hz}, 12 \mathrm{H}\right) .{ }^{13} \mathrm{C} \mathrm{NMR}\left(\mathrm{CDCl}_{3}, 75\right.$ $\mathrm{MHz}): \delta 166.4,163.5,151.0,145.1,135.9,121.9,117.2,99.4$, 75.4, 53.4, 28.4, 25.3, 19.3.; mp 253-255 ${ }^{\circ} \mathrm{C}$; HRMS (ESI) $\mathrm{m} / \mathrm{z}$ : Calcd. for $\mathrm{C}_{25} \mathrm{H}_{30} \mathrm{BrN}_{2} \mathrm{O}_{6}[\mathrm{M}+\mathrm{H}]^{+}$533.1287, Found 533.1287. X-ray Structure: see supporting information.

Dimethyl 1,8-diaza-4,5-diisobutoxy-9-\{[(tertbutoxycarbonyl)amino]methyl $\}-2,7$-anthracene dicarboxylate, 1-NHBoc. In a dry $50 \mathrm{~mL}$ round-bottomed flask 1-Br (5.00 g, $9.4 \mathrm{mmol})$ and potassium ditertbutylimino dicarbonate $^{37,40}$ ( $2.89 \mathrm{~g}, 11.3 \mathrm{mmol}, 1.2$ equiv.) were slurried in 20 $\mathrm{mL}$ of anhydrous DMF under an inert gas atmosphere. The flask was then heated to $50^{\circ} \mathrm{C}$ for 12 hours. Solvent was removed on the vacuum line and then the crude residue was dissolved in $10 \mathrm{~mL}$ of $\mathrm{MeCN}$. The mixture was heated to reflux and $\mathrm{Mg}\left(\mathrm{ClO}_{4}\right)_{2}(0.21 \mathrm{~g}, 0.9 \mathrm{mmol}, 0.1$ equiv. $)$ was added. The reaction was carefully monitored by TLC and stopped when the intermediate product is no longer visible ( 30 min). The reaction was diluted with $100 \mathrm{~mL}$ of EtOAc and washed with first water then brine solution. The organic layer was dried over $\mathrm{MgSO}_{4}$, filtered, and then solvent was removed by rotary evaporation. The crude yellow solid was recrystallized with $\mathrm{DCM} / \mathrm{MeOH}$ to give compound 1-NHBoc as a yellow solid (4.31 g, 81\%). ${ }^{1} \mathrm{H} \mathrm{NMR}\left(\mathrm{CDCl}_{3}, 300 \mathrm{MHz}\right): \delta 9.23(\mathrm{~s}$, $1 \mathrm{H}), 7.52(\mathrm{~s}, 2 \mathrm{H}), 6.4(\mathrm{bs}, 1 \mathrm{H}), 5.79(\mathrm{~d}, 2 \mathrm{H}),{ }^{3} J_{\mathrm{HH}}=5.6 \mathrm{~Hz}$, $4.15\left(\mathrm{~d},{ }^{3} J_{\mathrm{HH}}=6.4 \mathrm{~Hz}, 4 \mathrm{H}\right), 4.09(\mathrm{~s}, 6 \mathrm{H}), 2.37(\mathrm{~m}, 2 \mathrm{H}), 1.42(\mathrm{~s}$, 9H), $1.20\left(\mathrm{~d},{ }^{3} J_{\mathrm{HH}}=6.6 \mathrm{~Hz}, 12 \mathrm{H}\right) .{ }^{13} \mathrm{C} \mathrm{NMR}\left(\mathrm{CDCl}_{3}, 75\right.$ $\mathrm{MHz}): \delta$ 166.4, 163.7, 156.4, 150.4, 145.6, 145.6, 121.8, 116.0, 98.9, 78.8, 75.4, 53.3, 38.2, 28.7, 28.4, 19.3; mp 215$218{ }^{\circ} \mathrm{C}$; HRMS (ESI) m/z: Calcd. for $\mathrm{C}_{30} \mathrm{H}_{40} \mathrm{~N}_{3} \mathrm{O}_{8}[\mathrm{M}+\mathrm{H}]^{+}$ 570.2815 , Found 570.2817.

Dimethyl 1,8-diaza-4,5-diisobutoxy-9-[azidomethyl]-2,7anthracene dicarboxylate, $\mathbf{1 - N _ { 3 }}$. In a dry $50 \mathrm{~mL}$ roundbottomed flask 1-Br (1.00 g, $1.9 \mathrm{mmol})$ and sodium azide ( $0.52 \mathrm{~g}, 9.4 \mathrm{mmol}, 5.0$ equiv.) were slurried in $15 \mathrm{~mL}$ of dioxane. 15-crown-5 $(0.5 \mathrm{~mL})$ was added and the reaction was stirred at room temperature for 72 hours. Solvent was removed and the crude yellow solid was redissolved in $100 \mathrm{~mL}$ of dichloromethane. The solution was then filtered through celite to remove the residual salts. Solvent was removed on a rotary evaporator and the crude product was recrystallized from DCM/MeOH to give compound $\mathbf{1 - N _ { 3 }}$ as a yellow solid $(0.90 \mathrm{~g}$, 97\%). ${ }^{1} \mathrm{H} \mathrm{NMR}\left(\mathrm{CDCl}_{3}, 300 \mathrm{MHz}\right): \delta 9.29(\mathrm{~s}, 1 \mathrm{H}), 7.52(\mathrm{~s}$, $2 \mathrm{H}), 5.87(\mathrm{~s}, 2 \mathrm{H}), 4.15\left(\mathrm{~d},{ }^{3} J_{\mathrm{HH}}=6.2 \mathrm{~Hz}, 4 \mathrm{H}\right), 4.08(\mathrm{~s}, 6 \mathrm{H})$, $2.37(\mathrm{~m}, 2 \mathrm{H}), 1.20\left(\mathrm{~d},{ }^{3} \mathrm{~J}_{\mathrm{HH}}=6.6 \mathrm{~Hz}, 12 \mathrm{H}\right) .{ }^{13} \mathrm{C} \mathrm{NMR}\left(\mathrm{CDCl}_{3}\right.$, $75 \mathrm{MHz}): \delta$ 166.4, 163.6, 151.2, 146.1, 134.3, 121.8, 117.3, 99.3, 75.5, 53.3, 45.0, 28.5, 19.3; mp 231-235 ${ }^{\circ} \mathrm{C}$; HRMS (ESI) $\mathrm{m} / \mathrm{z}$ : Calcd. for $\mathrm{C}_{25} \mathrm{H}_{30} \mathrm{~N}_{5} \mathrm{O}_{6}[\mathrm{M}+\mathrm{H}]^{+} 496.2191$, Found 496.2194. X-ray Structure: see supporting information.

Dimethyl

1,8-diaza-4,5-diisobutoxy-9. [(acetyloxy)methyl]-2,7-anthracene dicarboxylate, 1-OAc. In a dry $50 \mathrm{~mL}$ round-bottomed flask $1-B r(1.00 \mathrm{~g}, 1.9 \mathrm{mmol})$ and silver acetate $(0.47 \mathrm{~g}, 2.8 \mathrm{mmol}, 1.5$ equiv.) were slurried in $30 \mathrm{~mL}$ of dioxane. The reaction was heated to $60{ }^{\circ} \mathrm{C}$ and stirred overnight. The solution was poured into dichloromethane $(100 \mathrm{~mL})$ then filtered through celite to remove the residual silver salts. Solvent was removed on a rotary evaporator and the crude product was recrystallized from $\mathrm{DCM} / \mathrm{MeOH}$ to give compound 1-OAc as a yellow solid $(0.80$ g, 91\%). ${ }^{1} \mathrm{H} \mathrm{NMR}\left(\mathrm{CDCl}_{3}, 300 \mathrm{MHz}\right): \delta 9.36$ (s, 1H), 7.54 (s, $2 \mathrm{H}), 6.68(\mathrm{~s}, 2 \mathrm{H}), 4.18\left(\mathrm{~d},{ }^{3} \mathrm{~J}_{\mathrm{HH}}=6.4 \mathrm{~Hz}, 4 \mathrm{H}\right), 4.11(\mathrm{~s}, 6 \mathrm{H})$, $2.40(\mathrm{~m}, 2 \mathrm{H}), 2.11(\mathrm{~s}, 3 \mathrm{H}), 1.23\left(\mathrm{~d},{ }^{3} J_{\mathrm{HH}}=6.7 \mathrm{~Hz}, 12 \mathrm{H}\right) .{ }^{13} \mathrm{C}$ NMR $\left(\mathrm{CDCl}_{3}, 75 \mathrm{MHz}\right): \delta 171.2,166.5,163.5,151.1,146.3$, 133.5, 121.6, 117.7, 99.0, 75.4, 58.0, 53.2, 28.4, 21.3, 19.3; mp 211-213 ${ }^{\circ} \mathrm{C}$; HRMS (ESI) m/z: Calcd. for $\mathrm{C}_{27} \mathrm{H}_{33} \mathrm{~N}_{2} \mathrm{O}_{8}$ $[\mathrm{M}+\mathrm{H}]^{+}$513.2237, Found 513.2235. X-ray Structure: see supporting information.

Dimethyl 1,8-diaza-4,5-diisobutoxy-9-(hydroxymethyl)2,7-anthracene dicarboxylate, 1-OH. In a dry $25 \mathrm{~mL}$ roundbottomed flask 1-Br $(0.60 \mathrm{~g}, 1.1 \mathrm{mmol})$ and silver carbonate (0.62 g, 2.3 mmol, 2.0 equiv.) were slurried in $10 \mathrm{~mL}$ of a $10 \% \mathrm{H}_{2} \mathrm{O}$ /dioxane solution under an inert gas atmosphere. The reaction was then stirred for 12 hours at $90{ }^{\circ} \mathrm{C}$. DCM $(30 \mathrm{~mL})$ was added and the solution was passed through celite to remove the precipitated silver salts. Solvent was removed on ed on a rotary evaporator and the crude yellow solid was recrystallized with $\mathrm{DCM} / \mathrm{MeOH}$ to give compound 1-OH as a yellow solid $(0.43 \mathrm{~g}, 80 \%)$. ${ }^{1} \mathrm{H}$ NMR $\left(\mathrm{CDCl}_{3}, 300 \mathrm{MHz}\right): \delta 9.22$ $(\mathrm{s}, 1 \mathrm{H}), 7.50(\mathrm{~s}, 2 \mathrm{H}), 6.36\left(\mathrm{t},{ }^{3} J_{\mathrm{HH}}=6.6 \mathrm{~Hz}, 1 \mathrm{H}\right), 6.15\left(\mathrm{~d},{ }^{3} J_{\mathrm{HH}}\right.$ $=6.4 \mathrm{~Hz}, 2 \mathrm{H}), 4.14\left(\mathrm{~d},{ }^{3} \mathrm{~J}_{\mathrm{HH}}=6.4 \mathrm{~Hz}, 4 \mathrm{H}\right), 4.08(\mathrm{~s}, 6 \mathrm{H}), 2.37$ $(\mathrm{m}, 2 \mathrm{H}), 1.20\left(\mathrm{~d},{ }^{3} \mathrm{~J}_{\mathrm{HH}}=6.8 \mathrm{~Hz}, 12 \mathrm{H}\right) .{ }^{13} \mathrm{C} \mathrm{NMR}\left(\mathrm{CDCl}_{3}, 75\right.$ $\mathrm{MHz}): \delta 166.1,163.8,150.0,145.3,137.9,121.6,115.9,98.9$, 75.4, 59.9, 53.4, 28.4, 19.3; mp 235-237 ${ }^{\circ} \mathrm{C}$; HRMS (ESI) $\mathrm{m} / \mathrm{z}$ : Calcd. for $\mathrm{C}_{25} \mathrm{H}_{31} \mathrm{~N}_{2} \mathrm{O}_{7}[\mathrm{M}+\mathrm{H}]^{+}$471.2131, Found 471.2126.

Dimethyl 1,8-diaza-4,5-diisobutoxy-9-(nitrooxymethyl)2,7-anthracene dicarboxylate, 1-ONO2. In a dry $50 \mathrm{~mL}$ 
round-bottomed flask 1-Br $(0.50 \mathrm{~g}, 0.9 \mathrm{mmol})$ and silver nitrate $(0.24 \mathrm{~g}, 1.4 \mathrm{mmol}, 1.5$ equiv.) were slurried in $20 \mathrm{~mL}$ of dioxane under an inert gas atmosphere. The reaction was then stirred for 12 hours at room temperature. DCM $(30 \mathrm{~mL})$ was added and the solution was passed through celite to remove the precipitated silver salts. Solvent was removed on a rotary evaporator and the crude yellow solid was recrystallized with $\mathrm{DCM} / \mathrm{MeOH}$ to give compound $\mathbf{1 - O N O} \mathbf{O}_{2}$ as a yellow solid $(0.39 \mathrm{~g}, 81 \%) .{ }^{1} \mathrm{H} \mathrm{NMR}\left(\mathrm{CDCl}_{3}, 300 \mathrm{MHz}\right): \delta 9.36(\mathrm{~s}, 1 \mathrm{H})$, $7.51(\mathrm{~s}, 2 \mathrm{H}), 7.07(\mathrm{~s}, 2 \mathrm{H}), 4.15\left(\mathrm{~d},{ }^{3} J_{\mathrm{HH}}=6.4,4 \mathrm{H}\right), 4.08(\mathrm{~s}$, $6 \mathrm{H}), 2.37(\mathrm{~m}, 2 \mathrm{H}), 1.20\left(\mathrm{~d},{ }^{3} \mathrm{~J}_{\mathrm{HH}}=6.8 \mathrm{~Hz}, 2 \mathrm{H}\right) .{ }^{13} \mathrm{C} \mathrm{NMR}$ $\left(\mathrm{CDCl}_{3}, 75 \mathrm{MHz}\right): \delta 166.1,163.5,151.6,146.5,128.8,121.5$, 119.0, 99.3, 75.5, 66.6, 53.3, 28.4, 19.3; mp 224-227 ${ }^{\circ} \mathrm{C}$; HRMS (ESI) m/z: Calcd. for $\mathrm{C}_{25} \mathrm{H}_{30} \mathrm{~N}_{3} \mathrm{O}_{9}[\mathrm{M}+\mathrm{H}]^{+}$516.1982, Found 516.1978. X-ray Structure: see supporting information.

\section{Dimethyl}

1,8-diaza-4,5-diisobutoxy-9[(methyloxy)methyl]-2,7-anthracene dicarboxylate, 1OMe. In a dry $25 \mathrm{~mL}$ round-bottomed flask 1-OAc $(0.10 \mathrm{~g}$, $0.2 \mathrm{mmol}$ ) was slurried in $20 \mathrm{~mL}$ of $\mathrm{MeOH}$. Concentrated sulfuric acid ( $0.01 \mathrm{~mL}, 0.2 \mathrm{mmol}, 1.0$ equiv.) was added and the reaction was stirred at reflux for 3 hours. The mixture was then neutralized with a saturated solution of $\mathrm{NaHCO}_{3}$ and the product was extracted with DCM. Solvent was removed on the rotovap and the crude yellow solid was recrystallized with $\mathrm{DCM} / \mathrm{MeOH}$ to give compound 1-OMe as a yellow solid (0.08 g, 80\%). ${ }^{1} \mathrm{H} \mathrm{NMR}\left(\mathrm{CDCl}_{3}, 300 \mathrm{MHz}\right): \delta 9.29(\mathrm{~s}, 1 \mathrm{H})$, $7.50(\mathrm{~s}, 2 \mathrm{H}), 5.97(\mathrm{~s}, 2 \mathrm{H}), 4.14\left(\mathrm{~d},{ }^{3} J_{\mathrm{HH}}=6.4,4 \mathrm{H}\right), 4.08(\mathrm{~s}$, $6 \mathrm{H}), 3.64(\mathrm{~s}, 3 \mathrm{H}), 2.36(\mathrm{~m}, 2 \mathrm{H}), 1.20\left(\mathrm{~d},{ }^{3} J_{\mathrm{HH}}=6.6 \mathrm{~Hz}, 12 \mathrm{H}\right)$. ${ }^{13} \mathrm{C} \mathrm{NMR}\left(\mathrm{CDCl}_{3}, 75 \mathrm{MHz}\right): \delta 166.5,163.4,151.0,146.5$, 135.8, 121.7, 117.1, 99.0, 75.3, 64.6, 59.4, 53.2, 28.4, 19.3; mp 211-214 ${ }^{\circ} \mathrm{C}$; HRMS (ESI) m/z: Calcd. for $\mathrm{C}_{26} \mathrm{H}_{33} \mathrm{~N}_{2} \mathrm{O}_{7}$ $[\mathrm{M}+\mathrm{H}]^{+}$485.2282, Found 485.2285.

Dimethyl 1,8-diaza-4,5-diisobutoxy-9-(formyl)-2,7anthracene dicarboxylate, $\mathbf{1}=\mathbf{0}$. In a dry $50 \mathrm{~mL}$ roundbottomed flask 1-ONO $2(0.40 \mathrm{~g}, 0.8 \mathrm{mmol})$ was slurried in 30 $\mathrm{mL}$ of dry dioxane. Triethylamine $(0.97 \mathrm{~mL}, 8.0 \mathrm{mmol}, 10.0$ equiv.) was added and the reaction was heated at $85{ }^{\circ} \mathrm{C}$ for 16 hours. The reaction was poured into ice water, and the product was extracted into DCM. Solvent was removed on a rotary evaporator and the crude yellow solid was purified by column chromatography with Cyclohexane/Acetone to give $\mathbf{1}=\mathbf{O}$ as a light yellow solid $(0.15 \mathrm{~g}, 41 \%) .{ }^{1} \mathrm{H} \mathrm{NMR}\left(\mathrm{CDCl}_{3}, 300 \mathrm{MHz}\right)$ : $\delta 11.86(\mathrm{~s}, 1 \mathrm{H}), 9.51(\mathrm{~s}, 1 \mathrm{H}), 7.58(\mathrm{~s}, 2 \mathrm{H}), 4.17\left(\mathrm{~d},{ }^{3} J_{\mathrm{HH}}=6.4\right.$, $4 \mathrm{H}), 4.09(\mathrm{~s}, 6 \mathrm{H}), 2.38(\mathrm{~m}, 2 \mathrm{H}), 1.21\left(\mathrm{~d},{ }^{3} J_{\mathrm{HH}}=6.8 \mathrm{~Hz}, 12 \mathrm{H}\right)$. ${ }^{13} \mathrm{C} \mathrm{NMR}\left(\mathrm{CDCl}_{3}, 75 \mathrm{MHz}\right): \delta 194.5,166.1,163.6,152.9$, 146.8, 129.4, 122.5, 121.7, 99.70, 75.6, 53.61, 28.4, 19.3; mp 252-255 ${ }^{\circ} \mathrm{C}$; HRMS (ESI) m/z: Calcd. for $\mathrm{C}_{25} \mathrm{H}_{29} \mathrm{~N}_{2} \mathrm{O}_{7}[\mathrm{M}+\mathrm{H}]^{+}$ 469.1975, Found 469.1970.

Dimethyl

1,8-diaza-4,5-diisobutoxy-9-[N(N'Methylimidazolium)methyl]-2,7-anthracene dicarboxylate, 1-imid. In a dry $50 \mathrm{~mL}$ round-bottomed flask 1-Br $(0.50 \mathrm{~g}, 0.9$ mmol) was slurried in $20 \mathrm{~mL}$ of methylimidazole. The reaction was then stirred overnight hours at $60{ }^{\circ} \mathrm{C}$. The solution was cooled to room temperature and diethyl ether $(100 \mathrm{~mL})$ was added. The powdery yellow product was collected by filtration and dried on the filter to give 1-imid as a yellow solid $(0.48 \mathrm{~g}, 83 \%) .{ }^{1} \mathrm{H} \mathrm{NMR}\left(\mathrm{CDCl}_{3}, 300 \mathrm{MHz}\right): \delta 9.55$ (s, 1H), $9.34(\mathrm{~s}, 1 \mathrm{H}), 7.88(\mathrm{~s}, 1 \mathrm{H}), 7.70(\mathrm{~s}, 1 \mathrm{H}), 7.53(\mathrm{~s}, 2 \mathrm{H}), 6.71$ $(\mathrm{s}, 2 \mathrm{H}), 4.18(\mathrm{~s}, 6 \mathrm{H}), 4.17\left(\mathrm{~d},{ }^{3} J_{\mathrm{HH}}=6.8 \mathrm{~Hz}, 4 \mathrm{H}\right), 4.15(\mathrm{~s}, 3 \mathrm{H})$, $2.38(\mathrm{~m}, 2 \mathrm{H}), 1.19\left(\mathrm{~d},{ }^{3} \mathrm{~J}_{\mathrm{HH}}=6.6 \mathrm{~Hz}, 12 \mathrm{H}\right) .{ }^{13} \mathrm{C} \mathrm{NMR}\left(\mathrm{CDCl}_{3}\right.$, $75 \mathrm{MHz}): \delta 165.7,164.1,151.8,145.4,137.4,129.7,124.2$, 123.0, 121.7, 119.4, 99.6, 75.7, 53.8, 43.9, 37.3, 28.3, 19.2; mp 192-195 ${ }^{\circ} \mathrm{C}$; HRMS (ESI) m/z: Calcd. for $\mathrm{C}_{29} \mathrm{H}_{35} \mathrm{~N}_{4} \mathrm{O}_{6}$ $[\mathrm{M}+\mathrm{H}]^{+}$535.2551, Found 535.2552.

Dimethyl 1,8-diaza-4,5-diisobutoxy-9-chloro-2,7anthracene dicarboxylate, $2-\mathrm{Cl}$. In a dry $1 \mathrm{~L}$ round-bottomed flask, a mixture of dimethyl 10-chloro-4,6-dioxo-1,4,6,9tetrahydropyrido[3,2-g]quinoline-2,8-dicarboxylate $(26.0 \mathrm{~g}$, $71.8 \mathrm{mmol})$, freshly distilled 2-methyl propanol $(15.2 \mathrm{~mL}$, 158.0 mmol, 2.2 equiv.) and triphenylphosphine (41.4 g, 158.0 mmol, 2.2 equiv.) was suspended in $500 \mathrm{~mL}$ anhydrous THF (freshly distilled). The flask was then hermetically closed and remained under protecting gas during the reaction time. (The reagents are not soluble in THF before the addition of diisopropyl azodicarboxylate). The reaction mixture was cooled to $0^{\circ} \mathrm{C}$ in an ice bath. DIAD (31.1 mL, $158.0 \mathrm{mmol}, 2.2$ equiv.) was then added slowly to this mixture, and the resulting solution was stirred at $0^{\circ} \mathrm{C}$ for $30 \mathrm{~min}$ and then overnight at room temperature. Solvents were rotary evaporated and the residue was re-crystallized from MeOH/DCM (2:2) by slow removal of the dichloromethane on the rotovap. Crystals were filtered using a fine sintered glass funnel and washed with cold methanol $\left(-18^{\circ} \mathrm{C}\right)$. The product was dried under reduced pressure to yield 2-Cl as a yellow solid $(24.1 \mathrm{~g}, 71 \%) .{ }^{1} \mathrm{H} \mathrm{NMR}\left(\mathrm{CDCl}_{3}\right.$, $300 \mathrm{MHz}): \delta 9.22(\mathrm{~s}, 1 \mathrm{H}), 7.57(\mathrm{~s}, 2 \mathrm{H}), 4.16\left(\mathrm{~d},{ }^{3} J_{\mathrm{HH}}=6.4 \mathrm{~Hz}\right.$, $4 \mathrm{H}), 4.11(\mathrm{~s}, 6 \mathrm{H}), 2.37(\mathrm{~m}, 2 \mathrm{H}), 1.21\left(\mathrm{~d},{ }^{3} \mathrm{~J}_{\mathrm{HH}}=6.8 \mathrm{~Hz}, 12 \mathrm{H}\right)$. ${ }^{13} \mathrm{C} \mathrm{NMR}\left(\mathrm{CDCl}_{3}, 75 \mathrm{MHz}\right): \delta 166.2,163.8,152.0,144.4$, 134.6, 122.5, 115.1, 99.8, 75.7, 53.7, 28.4, 19.3; mp 261-263 ${ }^{\circ} \mathrm{C}$; HRMS (ESI) m/z: Calcd. for $\mathrm{C}_{24} \mathrm{H}_{27} \mathrm{ClN}_{2} \mathrm{O}_{6}[\mathrm{M}+\mathrm{H}]^{+}$ 475.1636, Found 475.1634. X-ray Structure: see supporting information.

Dimethyl 1,8-diaza-4,5-diisobutoxy-9-amino-2,7anthracene dicarboxylate, $\mathbf{2}-\mathbf{N H}_{2}$. In a dry $25 \mathrm{~mL}$ roundbottomed flask 1-Cl $(0.50 \mathrm{~g}, 1.1 \mathrm{mmol})$ and triphenyl phosphine $(0.55 \mathrm{~g}, 2.2 \mathrm{mmol}, 2.0$ equiv.) were slurried in $8.5 \mathrm{~mL}$ of DMF. Sodium azide ( $0.14 \mathrm{~g}, 2.2 \mathrm{mmol}, 2.0$ equiv.) was added and the solution was heated to $120{ }^{\circ} \mathrm{C}$. The reaction was then monitored by TLC (50/50 Hex/EtOAc). When the starting material was no longer visible, $1 \mathrm{~N} \mathrm{HCl}(1.69 \mathrm{~mL})$ was added and the reaction was stirred for an additional 3 hours. Solvent was removed by azeotropic distillation with toluene on a rotary evaporator. The crude orange-red solid was purified by recrystallization from $\mathrm{DCM} / \mathrm{MeOH}$ to give compound 1-NH2 as a bright red solid $(0.30 \mathrm{~g}, 63 \%) .{ }^{1} \mathrm{H} \mathrm{NMR}\left(\mathrm{CDCl}_{3}, 300\right.$ $\mathrm{MHz}): \delta 8.19(\mathrm{~s}, 1 \mathrm{H}), 7.44(\mathrm{~s}, 2 \mathrm{H}), 6.68(\mathrm{bs}, 2 \mathrm{H}), 4.09\left(\mathrm{~d},{ }^{3} J_{\mathrm{HH}}\right.$ $=6.4 \mathrm{~Hz}, 4 \mathrm{H}), 4.06(\mathrm{~s}, 6 \mathrm{H}), 2.36(\mathrm{~m}, 2 \mathrm{H}), 1.18\left(\mathrm{~d},{ }^{3} J_{\mathrm{HH}}=6.8\right.$ $\mathrm{Hz}, 12 \mathrm{H}) .{ }^{13} \mathrm{C} \mathrm{NMR}\left(\mathrm{CDCl}_{3}, 75 \mathrm{MHz}\right): \delta 166.4,163.0,146.1$, $145.1,133.4,122.7,99.8,98.3,75.1,53.1,26.5,19.4$; mp 200$202{ }^{\circ} \mathrm{C}$; HRMS (ESI) m/z: Calcd. for $\mathrm{C}_{24} \mathrm{H}_{30} \mathrm{~N}_{3} \mathrm{O}_{6}[\mathrm{M}+\mathrm{H}]^{+}$ 456.2135, Found 456.2134. X-ray Structure: see supporting information.

Dimethyl 1,8-diaza-4,5-diisobutoxy-9-[bis(tertbutoxycarbonyl)amino]-2,7-anthracene dicarboxylate, 2NBoc2. In a dry $25 \mathrm{~mL}$ round-bottomed flask 2-NH2 $(0.25 \mathrm{~g}$, $0.5 \mathrm{mmol}$ ) was slurried in $4 \mathrm{~mL}$ of dioxane. Ditertbutyldicarbonate (1.20 g, $5.0 \mathrm{mmol}, 10.0$ equiv.) and diisopropylethylamine ( $0.28 \mathrm{~mL}, 5.0 \mathrm{mmol}, 10.0$ equiv.) and dimethylaminopyridine $(0.07 \mathrm{~g}, 0.5 \mathrm{mmol}, 1.0$ equiv.) were added and the solution was stirred overnight at $70{ }^{\circ} \mathrm{C}$. Solvent was removed and the crude yellow solid was purified by column chromatography with Cyclohexane/EtOAc (50/50). Solvent was removed on a rotary evaporator and the product was recrystallized from

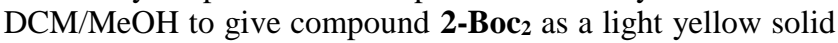
(0.29 g, 81\%). ${ }^{1} \mathrm{H}$ NMR $\left(\mathrm{CDCl}_{3}, 300 \mathrm{MHz}\right): \delta 9.22(\mathrm{~s}, 1 \mathrm{H})$, 
$7.48(\mathrm{~s}, 2 \mathrm{H}), 4.13\left(\mathrm{~d},{ }^{3} J_{\mathrm{HH}}=6.42 \mathrm{~Hz}, 4 \mathrm{H}\right), 4.01(\mathrm{~s}, 6 \mathrm{H}), 2.32$ $(\mathrm{m}, 2 \mathrm{H}), 1.34(\mathrm{~s}, 18 \mathrm{H}), 1.19\left(\mathrm{~d},{ }^{3} J_{\mathrm{HH}}=6.8 \mathrm{~Hz}, 12 \mathrm{H}\right) .{ }^{13} \mathrm{C} \mathrm{NMR}$ $\left(\mathrm{CDCl}_{3}, 75 \mathrm{MHz}\right): \delta 166.7,163.3,152.4,151.3,143.4,135.8$, 122.0, 116.0, 99.3, 82.1, 75.4, 52.9, 28.4, 28.0, 19.3; mp 207$212{ }^{\circ} \mathrm{C}$; HRMS (ESI) m/z: Calcd. for $\mathrm{C}_{34} \mathrm{H}_{46} \mathrm{~N}_{3} \mathrm{O}_{10}[\mathrm{M}+\mathrm{H}]^{+}$ 656.3183, Found 656.3196.

Dimethyl 1,8-diaza-4,5-diisobutoxy-9-[benzylmercato]2,7-anthracene dicarboxylate, 2-SBn. In a dry $25 \mathrm{~mL}$ roundbottomed flask 2-Cl $(1.00 \mathrm{~g}, 2.1 \mathrm{mmol})$, and $\mathrm{Cs}_{2} \mathrm{CO}_{3}(0.89 \mathrm{~g}$, $2.7 \mathrm{mmol}, 1.3$ equiv.) were slurried in $5 \mathrm{~mL}$ of toluene. Benzylmercaptan $(0.32 \mathrm{~mL}, 2.7 \mathrm{mmol}, 1.3$ equiv.) was added and the solution was stirred at room temperature overnight. Solvent was removed on a rotary evaporator and the crude orange-red solid was purified by column chromatography with Toluene/EtOAc (80/20). Solvent was removed on the rotovap and the product was recrystallized from $\mathrm{DCM} / \mathrm{MeOH}$ to give compound 2-SBn as a bright red solid (1.02 g, 86\%). ${ }^{1} \mathrm{H}$ NMR $\left(\mathrm{CDCl}_{3}, 300 \mathrm{MHz}\right): \delta 9.08(\mathrm{~s}, 1 \mathrm{H}), 7.53\left(\mathrm{dd}, J_{\text {ortho }}=6.5, J_{\text {meta }}=\right.$ $1.5 \mathrm{~Hz}, 2 \mathrm{H}), 7.49$ (s, 2H), 7.23-7.16 (m, 3H), 5.22 (s, 2H), $4.12\left(\mathrm{~d},{ }^{3} J_{\mathrm{HH}}=6.2,4 \mathrm{H}\right), 4.07(\mathrm{~s}, 6 \mathrm{H}), 2.35(\mathrm{~m}, 2 \mathrm{H}), 1.19(\mathrm{~d}$, $\left.{ }^{3} J_{\mathrm{HH}}=6.8 \mathrm{~Hz}, 12 \mathrm{H}\right) .{ }^{13} \mathrm{C} \mathrm{NMR}\left(\mathrm{CDCl}_{3}, 75 \mathrm{MHz}\right): \delta 166.5$, 163.7, 149.8, 147.0, 139.6, 136.8, 129.8, 128.3, 127.0, 122.1, 114.2, 99.2, 75.4, 53.3, 40.9, 28.5, 19.3; mp 217-219 ${ }^{\circ} \mathrm{C}$; HRMS (ESI) m/z: Calcd. for $\mathrm{C}_{31} \mathrm{H}_{35} \mathrm{~N}_{2} \mathrm{O}_{6} \mathrm{~S}[\mathrm{M}+\mathrm{H}]^{+} 563.2216$, Found 563.2221. X-ray Structure: see supporting information.

Dimethyl 1,8-diaza-4,5-diisobutoxy-9,10-dihydro-2,7anthracene dicarboxylate, $2-\mathbf{H}_{2}$. In a dry $250 \mathrm{~mL}$ roundbottomed flask, 2-Cl (10.0 g, $21.1 \mathrm{mmol}), \mathrm{K}_{2} \mathrm{CO}_{3}(20.4 \mathrm{~g}$, $147.7 \mathrm{mmol}, 7.0$ equiv.), and $10 \% \mathrm{Pd} / \mathrm{C}(2.2 \mathrm{~g})$ were slurried in $100 \mathrm{~mL}$ dry DMF. Nitrogen was then bubbled through the solution for 15 minutes to remove oxygen. The solution was then saturated with $\mathrm{H}_{2}$ by passing a stream of $\mathrm{H}_{2}$ through the solution for 15 minutes. The reaction was then kept under an atmosphere of $\mathrm{H}_{2}$ (provided by a balloon) for several hours (56 is usually sufficient) while carefully being monitored by TLC (1\% MeOH in DCM). When the starting material was no longer visible, the reaction was diluted with DCM and passed through celite. After removal of solvent on a rotary evaporator, the crude product was triturated with $\mathrm{MeOH}$ and collected by filtration. After drying on the vacuum line $\mathbf{2}-\mathbf{H}_{\mathbf{2}}$ was obtained as an off white solid $(7.3 \mathrm{~g}, 79 \%)$. ${ }^{1} \mathrm{H} \mathrm{NMR}\left(\mathrm{CDCl}_{3}\right.$, $300 \mathrm{MHz}): \delta 7.56(\mathrm{~s}, 2 \mathrm{H}), 4.50\left(\mathrm{t},{ }^{3} J_{\mathrm{HH}}=3.0 \mathrm{~Hz}, 2 \mathrm{H}\right), 4.05(\mathrm{t}$, $\left.{ }^{3} J_{\mathrm{HH}}=3.0 \mathrm{~Hz}, 2 \mathrm{H}\right), 4.01(\mathrm{~s}, 6 \mathrm{H}), 3.94\left(\mathrm{~d},{ }^{3} J_{\mathrm{HH}}=6.4 \mathrm{~Hz}, 4 \mathrm{H}\right)$, $2.21(\mathrm{~m}, 2 \mathrm{H}), 1.11\left(\mathrm{~d},{ }^{3} \mathrm{~J}_{\mathrm{HH}}=6.8 \mathrm{~Hz}, 12 \mathrm{H}\right) .{ }^{13} \mathrm{C} \mathrm{NMR}\left(\mathrm{CDCl}_{3}\right.$, $75 \mathrm{MHz}): \delta$ 166.2, 163.1, 155.7, 147.9, 120.9, 106.3, 74.8, 53.1, 40.2, 28.3, 22.1, 19.1; mp 213-216 ${ }^{\circ} \mathrm{C}$; HRMS (ESI) $\mathrm{m} / \mathrm{z}$ : Calcd. for $\mathrm{C}_{24} \mathrm{H}_{31} \mathrm{~N}_{2} \mathrm{O}_{6}\left[\mathrm{M}+\mathrm{H}-\mathrm{H}_{2}\right]^{+}$441.2026, Found 441.2024. The loss of hydrogen from protonated 9,10dihydroanthracenes, to give the $[\mathrm{M}-\mathrm{H}]^{+}$cation is an established phenomenon in 9,10-dihydroanthracenes. ${ }^{41} \mathrm{X}$-ray Structure: see supporting information.

Dimethyl 1,8-diaza-4,5-diisobutoxy-2,7-anthracene dicarboxylate, 2. Compound $\mathbf{2}-\mathbf{H}_{2}(5.0 \mathrm{~g}, 11.3 \mathrm{mmol})$ and dry carbon $(2.5 \mathrm{~g})$ were slurried in $50 \mathrm{~mL}$ of dry toluene in a 250 $\mathrm{mL}$ round-bottomed flask. The solution was placed under an $\mathrm{O}_{2}$ atmosphere and heated to $100{ }^{\circ} \mathrm{C}$ for 16 hours. The reaction was then diluted with $200 \mathrm{~mL}$ of DCM and poured onto a pad of silica. The product was then eluted with $2 \% \mathrm{MeOH}$ in DCM. Solvent was removed on a rotary evaporator and the product was recrystallized from $\mathrm{DCM} / \mathrm{MeOH}$ to give $\mathbf{2}$ as a bright yellow solid $(4.2 \mathrm{~g}, 84 \%){ }^{1} \mathrm{H} \mathrm{NMR}\left(\mathrm{CDCl}_{3}, 300 \mathrm{MHz}\right)$ : $\delta 9.27(\mathrm{~s}, 1 \mathrm{H}), 9.18(\mathrm{~s}, 1 \mathrm{H}), 7.51(\mathrm{~s}, 2 \mathrm{H}), 4.15\left(\mathrm{~d},{ }^{3} J_{\mathrm{HH}}=6.4\right.$
$\mathrm{Hz}, 4 \mathrm{H}), 4.11(\mathrm{~s}, 6 \mathrm{H}), 2.37(\mathrm{~m}, 2 \mathrm{H}), 1.20\left(\mathrm{~d},{ }^{3} J_{\mathrm{HH}}=6.8 \mathrm{~Hz}\right.$, 12H). ${ }^{13} \mathrm{C} \mathrm{NMR}\left(\mathrm{CDCl}_{3}, 75 \mathrm{MHz}\right): \delta$ 166.2, 163.3, 151.6, $147.7,131.0,122.0,116.9,99.1,75.3,53.5,28.3,19.2 ; \mathrm{mp}$ 244-246 ${ }^{\circ} \mathrm{C}$; HRMS (ESI) m/z: Calcd. for $\mathrm{C}_{24} \mathrm{H}_{29} \mathrm{~N}_{2} \mathrm{O}_{6}[\mathrm{M}+\mathrm{H}]^{+}$ 441.2026, Found 441.2022. X-ray Structure: see supporting information.

Dimethyl 1,8-diaza-4,5-diisobutoxy-9-bromo-2,7anthracene dicarboxylate, $2-\mathrm{Br}$. In a dry $25 \mathrm{~mL}$ roundbottomed flask, compound $2(0.50 \mathrm{~g}, 1.1 \mathrm{mmol})$ and freshly recrystallized NBS $(0.24 \mathrm{~g}, 1.3 \mathrm{mmol}, 1.2$ equiv. $)$ were slurried in $10 \mathrm{~mL}$ of a $1: 1$ mixture of $\mathrm{CHCl}_{3} / \mathrm{DMF}$. The solution was heated to $60{ }^{\circ} \mathrm{C}$ and stirred overnight. Solvent was then removed and the crude product was purified by column chromatography using $10 \%$ EtOAc/Toluene to obtain $2-\mathbf{B r}(0.41 \mathrm{~g}$, $70 \%) .{ }^{1} \mathrm{H}$ NMR $\left(\mathrm{CDCl}_{3}, 300 \mathrm{MHz}\right): \delta 9.29(\mathrm{~s}, 1 \mathrm{H}), 7.57(\mathrm{~s}$, $2 \mathrm{H}), 4.17\left(\mathrm{~d},{ }^{3} \mathrm{~J}_{\mathrm{HH}}=6.2 \mathrm{~Hz}, 2 \mathrm{H}\right), 4.11(\mathrm{~s}, 6 \mathrm{H}), 2.37(\mathrm{~m}, 2 \mathrm{H})$, $1.21\left(\mathrm{~d},{ }^{3} \mathrm{~J}_{\mathrm{HH}}=6.6 \mathrm{~Hz}, 12 \mathrm{H}\right) .{ }^{13} \mathrm{C} \mathrm{NMR}\left(\mathrm{CDCl}_{3}, 75 \mathrm{MHz}\right): \delta$ 166.2, 163.9, 152.3, 145.7, 122.9, 116.3, 99.7, 75.7, 53.7, 28.5, 27.1, 19.3; mp 253-259 ${ }^{\circ} \mathrm{C}$; HRMS (ESI) m/z: Calcd. for $\mathrm{C}_{24} \mathrm{H}_{28} \mathrm{BrN}_{2} \mathrm{O}_{6} \quad[\mathrm{M}+\mathrm{H}]^{+}$519.1131, Found 519.1132. X-ray Structure: see supporting information.

1,8-diaza-4,5-diisobutoxy-7-(methoxycarbonyl)-2anthracene carboxylic acid, 3. Compound 2 (4.00 g, 9.1 $\mathrm{mmol})$ was slurried in boiling $\mathrm{MeOH}(200 \mathrm{~mL})$ and heated at $65{ }^{\circ} \mathrm{C}$ with stirring until all solid dissolved. To this solution, $\mathrm{KOH}(0.76 \mathrm{~g}, 13.6 \mathrm{mmol}, 1.5$ equiv.) dissolved in $20 \mathrm{~mL}$ of $\mathrm{MeOH}$ was added dropwise. The reaction was stirred at $65^{\circ} \mathrm{C}$ until a precipitate was observed. The reaction was then cooled to $35{ }^{\circ} \mathrm{C}$ and stirred overnight. The solid was collected by filtration and washed with cold $\mathrm{MeOH}, 5 \%$ citric acid solution, and then water. After drying on the filter for 1 hour, the solid was redissolved in DCM and further dried over $\mathrm{Na}_{2} \mathrm{SO}_{4}$. The solution was then filtered and solvent removed on a rotary evaporator. After drying on the vacuum line $\mathbf{3}$ was obtained as a yellow solid $(3.50 \mathrm{~g}, 90 \%) .{ }^{1} \mathrm{H} \mathrm{NMR}\left(\mathrm{CDCl}_{3}, 300 \mathrm{MHz}\right): \delta$ $9.31(\mathrm{~s}, 1 \mathrm{H}), 9.04(\mathrm{~s}, 1 \mathrm{H}), 7.58(\mathrm{~s}, 1 \mathrm{H}), 7.55(\mathrm{~s}, 1 \mathrm{H}), 4.19(\mathrm{~d}$, $\left.{ }^{3} J_{\mathrm{HH}}=6.4 \mathrm{~Hz}, 2 \mathrm{H}\right), 4.17\left(\mathrm{~d},{ }^{3} J_{\mathrm{HH}}=6.4 \mathrm{~Hz}, 2 \mathrm{H}\right), 4.13(\mathrm{~s}, 3 \mathrm{H})$, $2.39(\mathrm{~m}, 2 \mathrm{H}), 1.21\left(\mathrm{~d},{ }^{3} J_{\mathrm{HH}}=6.8 \mathrm{~Hz}, 6 \mathrm{H}\right), 1.20\left(\mathrm{~d},{ }^{3} J_{\mathrm{HH}}=6.8\right.$ $\mathrm{Hz}, 6 \mathrm{H}) .{ }^{13} \mathrm{C} \mathrm{NMR}\left(\mathrm{CDCl}_{3}, 75 \mathrm{MHz}\right): \delta 166.1,165.0,164.3$, $163.6,152.2,150.3,147.9,145.5,129.3,122.4,122.1,117.8$, 99.6, 97.2, 76.0, 75.6, 53.7, 28.4, 28.4, 19.3, 19.3. HRMS (ESI) $\mathrm{m} / \mathrm{z}$ : Calcd. for $\mathrm{C}_{23} \mathrm{H}_{27} \mathrm{~N}_{2} \mathrm{O}_{6}[\mathrm{M}+\mathrm{H}]^{+}$427.1864, Found 427.1861 .

Sodium 1,8-diaza-4,5-diisobutoxy-7-(methoxycarbonyl)9-methyl-2-anthracene carboxylate, 3-Me. Compound 1 ( $10.0 \mathrm{~g}, 22.0 \mathrm{mmol}$ ) was placed in a $1 \mathrm{~L}$ round-bottomed flask and dissolved in $750 \mathrm{~mL}$ of THF:MeOH (75:25 v/v). NaOH ( $1.01 \mathrm{~g}, 25.3 \mathrm{mmol}, 1.15$ equiv.) dissolved in $\mathrm{MeOH}(20 \mathrm{~mL})$ was slowly added to this mixture. The reaction was then stirred at room temperature for 24 hours, during which time the product precipitates from solution. The white/yellow solid is collected by filtration and washed with cold $\mathrm{MeOH}$. The solid is dried under vacuum to give the sodium salt of the mono-carboxylate of $\mathbf{1}$ (3-Me) as a light yellow solid (9.1 g, $89 \%$ ). The compound was used in this form for subsequent reactions. However, because of the limited solubility of 3-Me in the carboxylate form, for characterization, $100 \mathrm{mg}$ of 3-Me was washed with a $5 \%$ citric acid solution and then extracted into $\mathrm{CHCl}_{3}$. After washing with water and brine, the solution was dried over $\mathrm{Na}_{2} \mathrm{SO}_{4}$. Solvent was removed on a rotary evaporator and then dried under vacuum to give the carboxylic acid. ${ }^{1} \mathrm{H} \mathrm{NMR}\left(\mathrm{CDCl}_{3}, 300 \mathrm{MHz}\right): \delta 9.19(\mathrm{~s}, 1 \mathrm{H}), 7.58(\mathrm{~s}, 1 \mathrm{H})$, 
$7.52(\mathrm{~s}, 1 \mathrm{H}), 4.18\left(\mathrm{~d},{ }^{3} J_{\mathrm{HH}}=6.4 \mathrm{~Hz}, 2 \mathrm{H}\right), 4.15\left(\mathrm{~d},{ }^{3} J_{\mathrm{HH}}=6.4\right.$ $\mathrm{Hz}, 2 \mathrm{H}), 4.11(\mathrm{~s}, 3 \mathrm{H}), 3.43(\mathrm{~s}, 3 \mathrm{H}) 2.38(\mathrm{~m}, 2 \mathrm{H}), 1.21\left(\mathrm{~d},{ }^{3} J_{\mathrm{HH}}\right.$ $=6.8 \mathrm{~Hz}, 6 \mathrm{H}), 1.20\left(\mathrm{~d},{ }^{3} \mathrm{~J}_{\mathrm{HH}}=6.8 \mathrm{~Hz}, 6 \mathrm{H}\right) .{ }^{13} \mathrm{C} \mathrm{NMR}\left(\mathrm{CDCl}_{3}\right.$, $75 \mathrm{MHz}): \delta 166.2,164.9,164.3,163.3,150.3,147.9,145.7$, 143.3, 137.1, 121.6, 121.1, 114.0, 99.2, 96.4, 75.7, 75.3, 53.3, 28.5, 28.4, 19.3, 19.2, 12.7. HRMS (ESI) m/z: Calcd. for $\mathrm{C}_{24} \mathrm{H}_{29} \mathrm{~N}_{2} \mathrm{O}_{6}[\mathrm{M}+\mathrm{H}]^{+}$441.2020, Found 441.2018.

\section{1,8-diaza-4,5-diisobutoxy-7-[(tert-}

butoxycarbonyl)amino]-2-anthracene carboxylate, 4 . In a dry $100 \mathrm{~mL}$ round bottomed flask equipped with a stir bar, $\mathbf{3}$ (3.46 g, $8.1 \mathrm{mmol}$ ) was slurried in $25 \mathrm{~mL}$ of dry toluene under a nitrogen atmosphere. DIPEA $(2.83 \mathrm{~mL}, 16.2 \mathrm{mmol}, 2$ equiv.) and DPPA (3.49 mL, $16.2 \mathrm{mmol}, 2$ equiv.) were added and the reaction was stirred at room temperature overnight. The reaction was then diluted with an additional $20 \mathrm{~mL}$ of dry toluene and anhydrous $t \mathrm{BuOH}(40 \mathrm{~mL})$ was added. The flask was then transferred to a $100{ }^{\circ} \mathrm{C}$ oil bath and stirred for 6 hours. Solvent was removed on a rotary evaporator and the crude material was redissolved in 1:1 DCM:MeOH. After slow evaporation of DCM on the rotovap, the solid product was collected by filtration and dried under vacuum to yield $\mathbf{4}$ as a light yellow solid $(2.49 \mathrm{~g}, 62 \%) .{ }^{1} \mathrm{H} \mathrm{NMR}\left(\mathrm{CDCl}_{3}, 300 \mathrm{MHz}\right): \delta 9.11(\mathrm{~s}$, 1H), $8.60(\mathrm{~s}, 1 \mathrm{H}), 7.68(\mathrm{~s}, 1 \mathrm{H}), 7.66(\mathrm{~s}, 1 \mathrm{H}), 7.44(\mathrm{~s}, 1 \mathrm{H}), 4.12$ $\left(\mathrm{d},{ }^{3} \mathrm{~J}_{\mathrm{HH}}=6.4 \mathrm{~Hz}, 2 \mathrm{H}\right), 4.11\left(\mathrm{~d},{ }^{3} J_{\mathrm{HH}}=6.4 \mathrm{~Hz}, 2 \mathrm{H}\right), 4.10(\mathrm{~s}$, $3 \mathrm{H}), 2.35(\mathrm{~m}, 2 \mathrm{H}), 1.55(\mathrm{~s}, 9 \mathrm{H}), 1.19\left(\mathrm{~d},{ }^{3} J_{\mathrm{HH}}=6.8 \mathrm{~Hz}, 6 \mathrm{H}\right)$, $1.18\left(\mathrm{~d},{ }^{3} J_{\mathrm{HH}}=6.8 \mathrm{~Hz}, 6 \mathrm{H}\right) \cdot{ }^{13} \mathrm{C} \mathrm{NMR}\left(\mathrm{CDCl}_{3}, 75 \mathrm{MHz}\right): \delta$ 166.6, 163.6, 163.4, 154.7, 152.7, 151.0, 148.2, 147.4, 126.1, $120.8,119.4,116.8,98.3,92.4,81.6,75.2,75.0,53.5,28.4$, 19.4, 19.3; mp 258-263 ${ }^{\circ} \mathrm{C}$; HRMS (ESI) m/z: Calcd. for $\mathrm{C}_{27} \mathrm{H}_{36} \mathrm{~N}_{3} \mathrm{O}_{6}[\mathrm{M}+\mathrm{H}]^{+}$498.2604, Found 498.2605.

Methyl 1,8-diaza-4,5-diisobutoxy-7-[(tertbutoxycarbonyl)amino]-9-methyl-2-anthracene carboxylate, 4-Me. The sodium salt of 3-Me (10.0 g, $21.7 \mathrm{mmol})$, in a nitrogen flushed $250 \mathrm{~mL}$ round bottom flask equipped with a septum and stir bar, was slurried in dry DCM $(50 \mathrm{~mL})$. A needle was inserted into the septa to act as a gas vent while, oxalyl chloride (12.9 mL, $151.6 \mathrm{mmol}, 7$ equiv.) was added slowly to the mixture via a syringe. The reaction was stirred for 2-4 hours at room temperature after which time the solution turned orange and appeared slightly cloudy. Solvent was removed under vacuum and the yellow-orange solid further dried on a vacuum line for 4 hours. The solid was then redissolved in dry DCM $(50 \mathrm{~mL})$ and trimethylsilyl azide $(8.5 \mathrm{~mL}$, 65.0 mmol, 3 equiv.) was added. The mixture was then allowed to stir overnight (12 hours) at room temperature. Solvent was removed under vacuum. Anhydrous $t \mathrm{BuOH}(50 \mathrm{~mL})$ was then added via syringe and the resulting yellow slurry refluxed for 12 hours. Solvent was removed with a rotary evaporator. The crude solid was then dissolved in DCM and filtered through celite. After removal of solvent, the mixture was recrystallized by slow evaporation of DCM from a 2:1 mixture of DCM:MeOH to give 4-Me as a bright yellow solid (8.5 g, 77\%). ${ }^{1} \mathrm{H} \mathrm{NMR}\left(\mathrm{CDCl}_{3}, 300 \mathrm{MHz}\right): \delta 9.01(\mathrm{~s}, 1 \mathrm{H}), 7.67$ $(\mathrm{s}, 1 \mathrm{H}), 7.56(\mathrm{~s}, 1 \mathrm{H}), 7.42(\mathrm{~s}, 1 \mathrm{H}), 4.11\left(\mathrm{~d},{ }^{3} J_{\mathrm{HH}}=6.4 \mathrm{~Hz}, 4 \mathrm{H}\right)$, 4.08 (s, 3H), 3.23 (m, 3H), 2.34 (m, 2H), 1.57 (s, 9H), 1.19 (d, $\left.{ }^{3} J_{\mathrm{HH}}=6.8 \mathrm{~Hz}, 6 \mathrm{H}\right), 1.18\left(\mathrm{~d},{ }^{3} J_{\mathrm{HH}}=6.4 \mathrm{~Hz}, 6 \mathrm{H}\right) .{ }^{13} \mathrm{C} \mathrm{NMR}$ $\left(\mathrm{CDCl}_{3}, 75 \mathrm{MHz}\right): \delta 166.7,163.6,163.5,152.9,152.6,149.3$, $146.2,145.2,133.6,119.9,119.0,113.4,97.7,91.9,81.3$, 74.9, 53.2, 28.4, 19.3, 12.6; mp 233-235 ${ }^{\circ} \mathrm{C}$; HRMS (ESI) $\mathrm{m} / \mathrm{z}$ : Calcd. for $\mathrm{C}_{28} \mathrm{H}_{38} \mathrm{~N}_{3} \mathrm{O}_{6}[\mathrm{M}+\mathrm{H}]^{+}$512.2761, Found 512.2760 .

\section{ASSOCIATED CONTENT}

Supporting Information: NMR spectra for all compounds and crystallographic data for compounds 1-Br, 1-ONO2, 1-OAc, 1$\mathbf{N}_{3}, \mathbf{2}-\mathrm{Cl}, \mathbf{2}-\mathrm{H}_{2}, 2,2-\mathrm{NH}_{2}, \mathbf{2}-\mathrm{SBn}, \mathbf{2 - B r}$ and byproducts 2-Clred and 4-dimer. This material is available free of charge via the Internet at http://pubs.acs.org.

\section{AUTHOR INFORMATION}

\section{Corresponding Author}

*E-mail: i.huc@iecb.u-bordeaux.fr

\section{Author Contributions}

The manuscript was written through contributions of all authors. All authors have given approval to the final version of the manuscript.

\section{ACKNOWLEDGMENT}

This work was supported by the European Union's Seventh Framework Programme through Marie Curie actions (PIIF-GA2010-275209 post-doctoral fellowship to MLS) and through the European Research Council (Grant Agreements No. ERC-2012AdG-320892), by COST action CM0803 (travel grant to NC) and by the Fondation Simone et Cino Del Duca de l'Institut de France (Post-Doctoral Fellowship to MLS).

\section{REFERENCES}

(1) Goodman, C. M.; Choi, S.; Shandler, S.; DeGrado, W. F. Nat. Chem. Biol. 2007, 3, 252.

(2) Guichard, G.; Huc, I. Chem. Commun. 2011, 47, 5933.

(3) Montalvo, G.; Waegele, M. M.; Shandler, S.; Gai, F.; DeGrado, W. F. J. Am. Chem. Soc. 2010, 132, 5616.

(4) Dohm, M. T.; Mowery, B. P.; Czyzewski, A. M.; Stahl, S. S.; Gellman, S. H.; Barron, A. E. J. Am. Chem. Soc. 2010, 132, 7957.

(5) Zhao, Y.; Zhong, Z. J. Am. Chem. Soc. 2006, 127, 17894.

(6) Odriozola, I.; Kyritsakas, N.; Lehn, J.-M. Chem. Commun. 2004, 62

(7) Jamieson, A. G.; Russell, D.; Hamilton, A. D.; Chem. Commun. 2012, 48, 3709 .

(8) Cheng, P.-N.; Spencer, R.; Woods, J. R.; Glabe, C. G.; Nowick, J. S. J. Am. Chem. Soc. 2012, 134, 14179.

(9) Appella, D. H.; Christianson, L. A.; Karle, I. L.; Powell, D. R.; Gellman, S. H. J. Am. Chem. Soc. 1996, 118, 13071.

(10) Cheng, R. P.; Gellman, S. H.; DeGrado, W. F. Chem. Rev. 2001, 101, 3219.

(11) Seebach, D.; Beck, A. K.; Bierbaum, D. J. Chem. Biodivers. 2004, 1, 1111.

(12) Li, X.; Wu, Y. D.; Yang, D. Acc. Chem. Res. 2008, 41, 1428.

(13) Stone, M. T.; Heemstra, J. M.; Moore, J. S. Acc. Chem. Res. 2006, 39, 11 .

(14) Leung, S. Y.-L.; Tam, A. Y.-Y.; Tao, C.-H.; Chow, H. S.; Yam, V. W.-W. J. Am. Chem. Soc. 2012, 134, 1047.

(15) Azeroual, S.; Surprenant, J.; Lazzara, T. D.; Kocun, M.; Tao, Y.; Cuccia, L. A.; Lehn, J. -M. Chem. Commun. 2012, 48, 2292.

(16) Cuccia,L. A.; Ruiz, E.; Lehn, J.-M.; Homo, J. C.; Schmutz, M. Chem. Eur. J. 2002, 8, 3448.

(17) Fremaux, J.; Fischer, L.; Arbogast, T.; Kauffmann, B.; Guichard, G. Angew. Chem. Int. Ed. 2011, 50, 11382.

(18) Mousseau, J. J.; Xing, L.; Tang, N.; Cuccia, L. A. Chem. Eur. J. 2009, 15, 10030.

(19) Zhang, D-.W.; Zhao, X.; Hou, J.-L.; Li, Z.-T. Chem. Rev. 2012, 112, 5271 .

(20) Huc, I. Eur. J. Org. Chem. 2004, 17.

(21) Yamato, K.; Kline, M.; Gong, B. Chem. Commun. 2012, 48, 12142.

(22) Juwarker, H.; Suk, J.-m.; Jeong, K.-S. Chem. Soc. Rev. 2009, 38,3316

(23) Ferrand, Y.; Kendhale, A. M.; Kauffmann, B.; Grélard, A.; Marie,C.; Blot, V.; Pipelier, M.; Dubreuil, D.; Huc, I. J. Am. Chem. Soc. 2010, 132, 7858 
(24) Bao, C.; Gan, Q.; Kauffmann, B.; Jiang, H.; Huc, I. Chem. Eur. J. 2009, 15, 11530.

(25) Bao, C.; Kauffmann, B.; Gan, Q.; Srinivas, K.; Jiang, H.; Huc, I. Angew. Chem. Int. Ed. 2008, 47, 4153.

(26) Berni, E.; Garric, J.; Lamit, C.; Kauffmann, B.; Léger, J. -M.; Huc, I. Chem. Commun. 2008, 1968.

(27) Hall, C. M.; Wright, J. B.; Johnson, H. G.; Taylor, A. J. J. Med. Chem. 1977, 20, 1337.

(28) Cheney, B. V.; Christoffersen, R. E. J. Med. Chem. 1983, 26, 726.

(29) Jain, R.; Caldwell, S. L.; Louie, A. S.; Hicks, R. G. Can. J. Chem. 2006, 84, 1263.

(30) Zhang, J.; Karabunarliev, S.; Baumgarten, M. Chem. Phys. 1996, 339.

(31) Gan, Q.; Shang, J.; Kauffmann, B.; Wang, Y.; Bie, F.; Jiang, H. Tetrahedron Lett. 2012, 68, 4479.

(32) Gan, Q.; Ferrand, Y.; Bao, C.; Kauffmann, B.; Grélard, A.; Jiang, H.; Huc, I. Science 2011, 331, 1172.

33) Berni, E.; Dolain, C.; Kauffmann, B.; Leger, J. -M.; Zhan, C.; Huc, I. J. Org. Chem. 2008, 73, 2687.

(34) Berni, E.; Kauffmann, B.; Bao, C.; Lefeuvre, J.; Bassani, D. M.; Huc, I. Chem. Eur. J. 2007, 13, 8463.

(35) Zewge, D.; Chen, C.-y.; Deer, C.; Dormer, P. G.; Hughes, D. L. J. Org. Chem. 2007, 72, 4276.

(36) Based on the results reported herein, the 9-hydro derivative reported in: Zhu, H.; Guan, Z.; Zhan, C. Youji Huaxue 2010, 30, 1716 , is rather an impurity that has been mistaken for their desired product.

(37) Grehn, L.; Ragnarsson, U. Synthesis 1987, 3, 275.

(38) Kandalkar, S. R.; Kaduskar, R. D.; Ramaiah, P. A.; Barawkar, D. A.; Bhuniya, D.; Deshpande, A. M. Tetrahedron Lett. 2013, 54, 414.

(39) Hayashi, M. The Chemical Record 2008, 8, 252.

(40) Zhou, J.; Matos, M. -C.; Murphy, P. V. Org. Lett. 2011, 13, 5716.

(41) Vala, M.; Szczepanski, J.; Oomens, J. Int. J. Mass. Spec.

2011, 308, 181 .

Graphic entry for the Table of Contents (TOC)

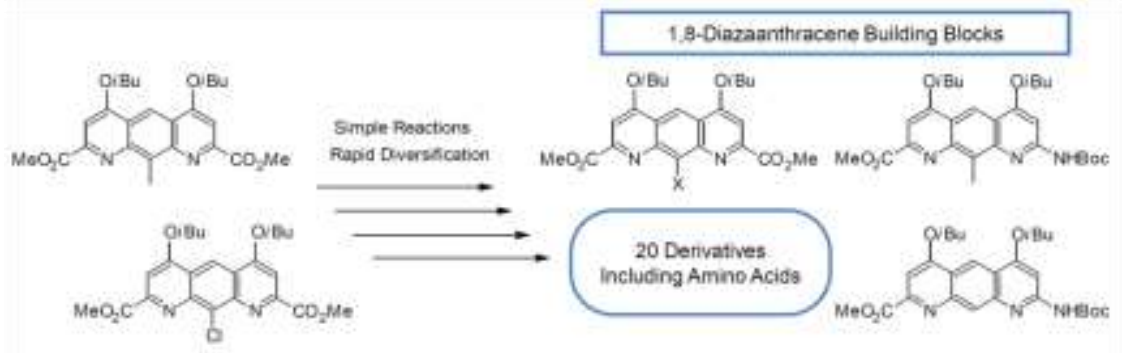

